\title{
POŠTA
}

TELEKOMUNIKÁCIE A

ELEKTRONICKY OBCHOD

\section{PREFERENCIE A SPOKOJNOSŤ SLOVENSKÝCH ZÁKAZNÍKOV SO SLUŽBAMI DODANIA TOVARU V RÁMCI POSLEDNEJ MÍLE}

\author{
Peter Jucha $^{1}$, Tomáš Benko ${ }^{2}$, Tatiana Čorejová ${ }^{3}$
}

\begin{abstract}
The main goal of the paper is to identify the preferences and satisfaction of customers with delivery services within the last mile. To this end, a questionnaire survey was conducted, which showed that consumers prefer delivery by courier, payment by card online and can already imagine to a large extent the delivery of goods by drone.
\end{abstract}

Keywords: customer, delivery services, last mile

\section{Úvod}

Business to Consumer (B2C) predstavuje jeden zo vzt'ahov v rámci elektronického obchodu a označuje model elektronického obchodu, v ktorom firmy predávajú produkty alebo služby jednotlivým kupujúcim. Objemy online B2C transakcií každoročne narastajú. [1]

Nárast online predaja $\mathrm{v}$ rámci modelu $\mathrm{B} 2 \mathrm{C}$ mal za následok fragmentáciu nákladných zásielok, a poskytovatelia logistických služieb tak stoja pred výzvou vyrovnania sa konkurencii, spotrebitel'skou ekonomikou, problémami spojenými s neúspešnými dodávkami a mnohými d’alšími. [2] Vel'ká čast' takýchto problémov sa spája s dodaním tovaru zákazníkovi a teda s poslednou čast'ou dodávatel'ského ret'azca, ktorý sa najčastejšie označuje ako „posledná míl'a“. Tá predstavuje posledný úsek prepravy produktu ku konečnému zákazníkovi alebo predajnému miestu a často sa považuje za najdôležitejší prvok procesu vybavovania objednávky. [3] Nápor a nárast elektronického obchodu, ktorý je poháňaný hlavne spotrebitel'mi, pochádza predovšetkým z tejto poslednej časti dodávatel'ského ret'azca, čiže z poslednej míle. Klúčoví aktéri poslednej míle čelia $\mathrm{v}$ súčasnosti najmä výzvam spojeným s zvyšovaním požiadaviek zákazníkov. [4]

Preferencie spotrebitel'ov sa stávajú hlavným problémom marketingu. Monitorovanie spotrebitel'ských online komentárov a hodnotení produktov sa stáva rozhodujúce pre dostatočné porozumenie spätnej väzby a preferencií spotrebitel'ov. [5] Tieto preferencie spotrebitel'ov sú ovplyvnené faktormi, akými sú napríklad porovnanie tovaru, dodania tovaru domov alebo na určené miesto, pohodlie nákupu a pod. [6]

Preferencie zákazníkov sú úzko spojené aj s ich spokojnost'ou, ktorú je možné definovat' ako reakciu (emocionálnu alebo afektívnu), ktorá sa týka nejakého konkrétneho zamerania, produktu, skúsenosti so spotrebou a pod. [7] Poznanie úrovne spokojnosti zákazníkov umožňuje podnikom úspešne transformovat' zákazníka na spotrebitel’a. Zameranie na spokojnost' zákazníkov je nevyhnutné pre vytvorenie východiskového bodu pre získanie lojality zákazníkov. [8]

\footnotetext{
${ }^{1}$ Ing. Peter Jucha, Žilinská univerzita, Univerzitná 8215/1, 01026 Žilina, Slovensko, e-mail: peter.jucha@fpedas.uniza.sk

${ }^{2}$ Bc. Tomáš Benko, Žilinská univerzita, Univerzitná 8215/1, 01026 Žilina, Slovensko, e-mail: benko17@stud.uniza.sk

${ }^{3}$ Dr.h.c prof. Ing. Tatiana Čorejová, PhD., Žilinská univerzita, Univerzitná 8215/1, 01026 Žilina, Slovensko, e-mail: tatiana.corejova@uniza.sk
} 
Ekonomický vývoj v ére globalizácie je ale stále komplexnejší a zákazníci a spotrebitelia tak stoja pred mnohými možnost’ami výberu tovarov a služieb. [9]

\section{Ciel' a metodológia}

Hlavným ciel'om príspevku bolo identifikovat', aké sú preferencie a spokojnost' zákazníkov so službami dodania tovaru v rámci poslednej míle. Konkrétne ide preferencie a spokojnost' zákazníkov pri možnosti platby za tovar, pri výbere služby dodania tovaru, spokojnost' s konkrétnymi službami, ale aj ich preferencie pri možnom budúcom spôsobe dodania tovaru $\mathrm{v}$ rámci poslednej míle.

Východiskovým zdrojom pre definovanie metodologického postupu pri zist'ovaní preferencií a spokojnosti zákazníkov s procesom dodania tovaru bola analýza literárnych zdrojov z databázy Web of Science. Pre potreby spracovania výsledkov príspevku bol následne navrhnutý a realizovaný dotazníkový prieskum v elektronickej podobe. Dotazník bol zdiel'aný prostredníctvom sociálnej siete Facebook. Pri 95\% spol'ahlivosti odhadu a chybovosti $5 \%$ a po dosadení príslušných hodnôt, spolu s tabul'kovou hodnotou $t^{2}=3,8416$ a $\sigma^{2}=0,25$, do príslušného vzorca, predstavovalo ciel'ovú vzorku 383 respondentov

$$
n \geq t_{1-\frac{\alpha}{2}}^{2} * \frac{\sigma^{2}}{\Delta^{2}}
$$

kde:

$\mathrm{n}$ - vel'kost' súboru,

$t^{2} \_(1-\alpha / 2)$ - je kritická hodnota určená z tabuliek (kritické hodnoty normalizovaného normálneho rozdelenia),

$\sigma 2$ - je rozpätie vypočítané zo štandardnej odchýlky,

$\Delta-$ je maximáln povoelná miera chybovosti.

Odpovede z dotazníka boli následne vyhodncované slovne a graficky.

\section{Výsledky}

Nasledujúca čast' sa venuje prezentácii výsledkov prieskumu, ktorý bol zrealizovaný za účelom zistenia preferencií a spokojnosti zákazníkov so službami dodania tovaru v rámci poslednej míle.

Prvá otázka sa týka toho, aký spôsob dodania tovaru v súčasnosti zákazníci preferujú alebo uprednostňujú. Podl'a DigitalCommerce360.com si až $54 \%$ spotrebitel'ov vyberá eshop na základe toho ako im bude tovar dodaný. [10] Zákazníci majú pritom v súčasnosti na výber niekol'ko možností akými sú dodanie tovaru s využitím služieb pošty, iných poštových podnikov (GLS, DPD, DHL Zásielkovňa atd'.), vyzdvihnutie v balíkomate alebo osobný odber v kamennej predajni prípadne na inom odbernom mieste. 


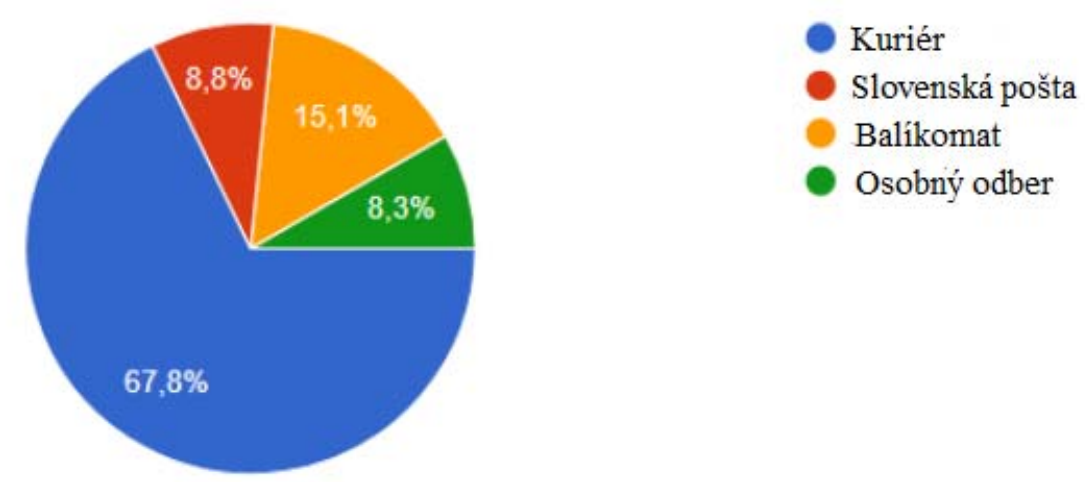

Obrázok 1: Preferencia spôsobu dodania tovaru Zdroj: Autor

Až takmer $70 \%$ respondentov označilo, že preferujú dodanie tovaru kuriérom. Konkrétne išlo o 259 respondentov. Druhou najčastejšie označovanou odpoved'ou bol balíkomat, ktorý si vybralo 58 respondentov. Služby Slovenskej pošty pri dodaní tovaru (s výnimkou dodania tovaru kuriérom) využíva 34 respondentov a osobný odber preferuje 32 respondentov.

Ďalšia otázka sa zameriaval na to aké poštové podniky spotrebitelia preferujú. Na Slovensku ich figuruje niekol'ko a respondenti mali na výber z tých, ktoré dosahujú najvyššie tržby. Okrem toho tam mali aj možnost' zvolit' poštového kuriéra.
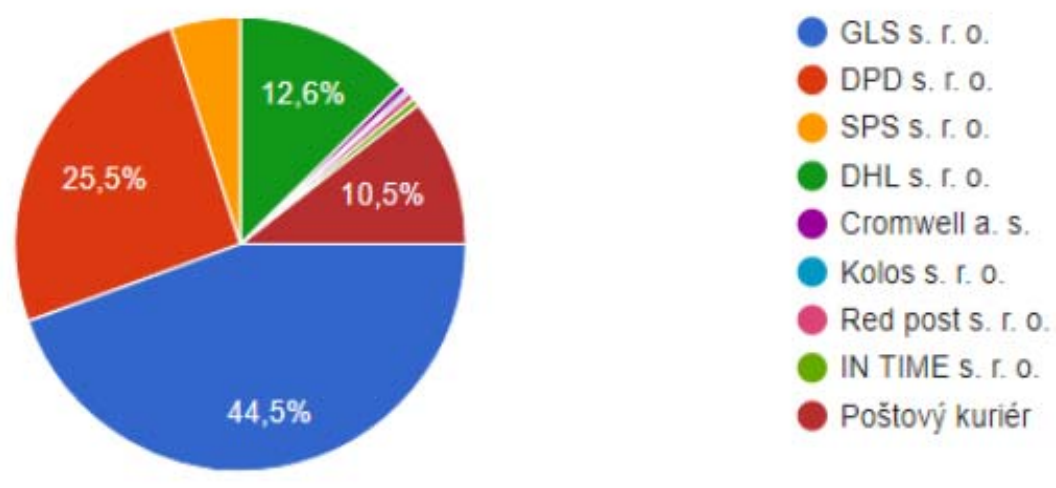

Obrázok 2: Preferované poštové podniky Zdroj: Autor

Necelých $45 \%$ respondentov, konkrétne 171, považuje za najspol'ahlivejší poštový podnik GLS s.r.o. Nasledoval poštový podnik DPD s.r.o., ktorý považuje za najspol'ahlivejší 98 respondentov. Na tret'om mieste sa umiestnil poštový podnik DHL s.r.o., ktorý označilo 48 respondentov. Za ním nasledoval poštový podnik Slovenská pošta a konkrétne jej kuriérska služba, ktorú označilo 40 respondentov. Poštový podnik SPS s.r.o. zvolilo za najspol'ahlivejší 19 respondentov. Nasledovali poštové podniky Cromwell, RED post a IN time, kde každý z nich označili dvaja respondenti. Na poslednom mieste ostal poštový podnik KOLOS, ktorý si vybral iba jeden respondent. 
Vel'a l'udí na Slovensku v súčasnosti stále využíva pri dodaní tovaru aj služby Slovenskej pošty. Preto sa prieskum zameral aj na spokojnost' spotrebitel'ov práve so službami pošty.

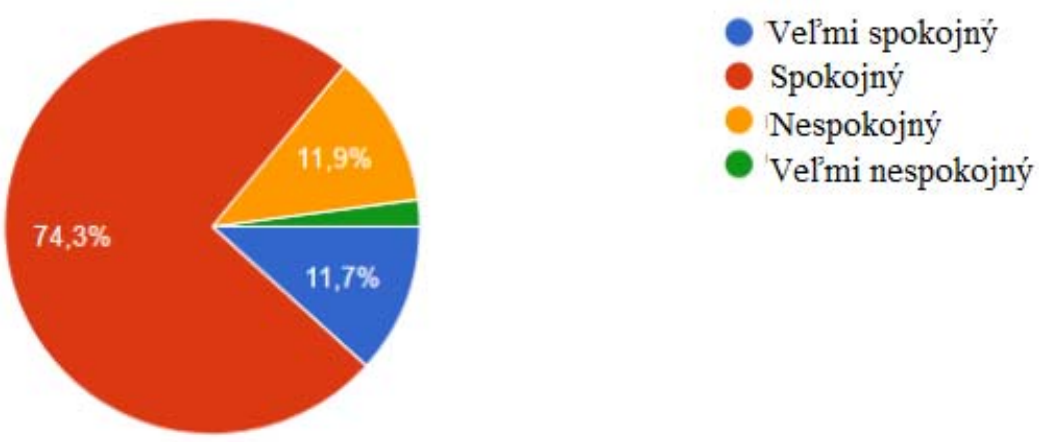

Obrázok 3: Spokojnost' respondentov s cenou za dopravu Zdroj: Autor

So službami Slovenskej pošty je vel'mi spokojných iba 11,7 \% respondentov, pričom tieto percentá predstavujú konkrétne 45 respondentov. Takmer rovnaký počet respondentov, 46, je so službami Slovenskej pošty nespokojných. Oproti tomu až 74,3\% respondentov, čo konkrétne predstavuje 285 respondentov, je so službami Slovenskej pošty spokojných. A iba 7 respondentov, je so službami Slovenskej pošty vel'mi nespokojncýh.

Štvrtá otázka bola zameraná na spokojnost' spotrebitel'ov s cenou za dopravu. Mnoho ludí s cenou nezvykne byt' spokojných a prijali by keby boli ceny nižšie.

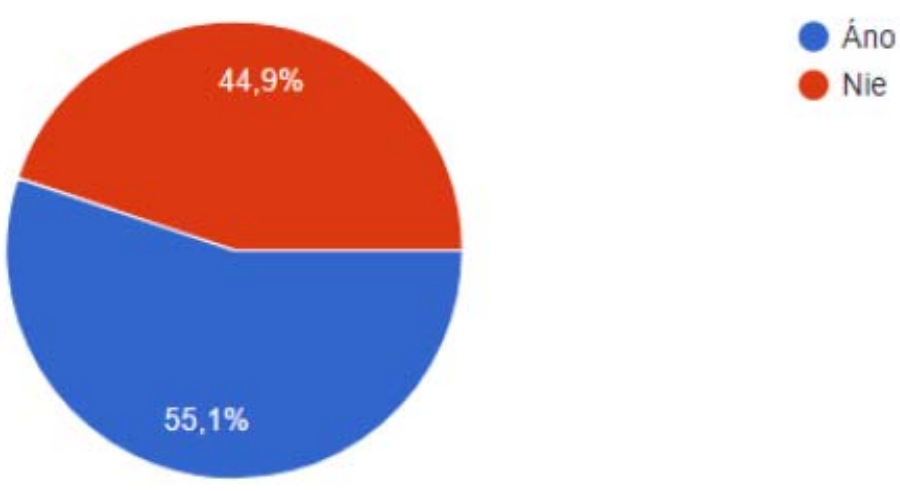

Obrázok 4: Spokojnost' respondentov s cenou za dopravu Zdroj: Autor

S tým, či je cena za dopravu primeraná, súhlasí 55,1 \% respondentov, čo konkrétne predstavuje 211 respondentov. Cena za dopravu nie je primeraná podl'a 172 respondentov.

Súčast'ou otázok, týkajúcich sa preferencií spotrebitel'ov pri dodaní tovaru v rámci poslednej míle, je aj otázka týkajúca sa preferencie platby za objednávku alebo tovar. Niektorí spotrebitelia sa rozhodnú zaplatit' za objednávku až pri jej prevzatí pokial' je to možné. Aj z toho dôvodu bola táto otázka súčast'ou prieskumu. Na základe údajov z internetu, je zrejmé, že v súčasnosti už Slováci viac využívajú bezhotovostné platby ako platenie fyzickými 
peniazmi. Tomuto trendu jednoznačne pomohla aj možnost' platit' za nákup bezkontaktne, ktorá je tu už niekol'ko rokov. [11]

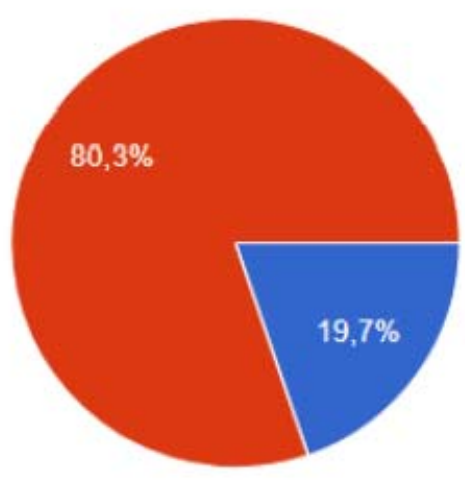

\section{Obrázok 5: Preferencia platby Zdroj: Autor}

Až 80,3\% respondentov, konkrétne tak 308, uviedlo, že preferujú platbu kartou online za tovaru. A len 76 respondentov v súčasnosti stále uprednostňuje platbu v hotovosti.

Posledná otázka bola zameraná na budúcnost' dodania tovaru $\mathrm{k}$ spotrebitel'om. Ide o spôsob dodania tovaru spotrebitel'om prostredníctvom dronu. Je to jedna z možností, ktorá sa už pomaly v niektorých krajinách stáva skutočnost’ou a začína sa zavádzat'. Neikol'ko doručovacích spoločností vo svete už začalo s využívaním dronov, ktoré sú schopné dodat' tovar priamo zákazníkovi. Napriek tomu je stále potrebné prekonat' určité výzvy, ktoré sa s využitím dronov spájajú. Využívat' sa preto budú pravdepodobne predovšetkým na dodanie balíkov do t’ažko prístupných miest, alebo v prípade vzniknutia mimoriadnych okolností. [12]

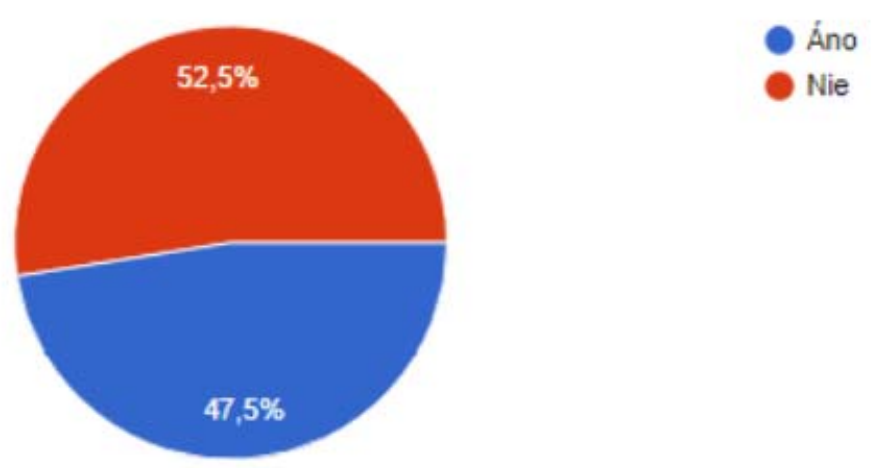

Obrázok 6: Preferencia dodania tovaru dronom Zdroj: Autor

$\mathrm{Na}$ otázku, čo by respondenti preferovali dodanie tovaru dronom, väčšina $\mathrm{z}$ nich odpovedala, že nie. Konkrétne to bolo 201 respondentov. Oproti tomu 182 respondentov by takúto možnost' dodania tovaru v súčasnosti už prijalo. 


\section{Záver}

Z uskutočneného prieskumu jednoznačne vyplýva, že zákazníci v súčasnosti preferujú dodanie tovaru kuriérom. Ide o možnost', ktorá sa javí ako najpohodlnejšia, pretože zákazníkom umožňuje nechat' si tovar dodat' kamkol'vek chcú. Okrem toho ide aj o najrýchlejší spôsob dodania tovaru. Zvyčajne je zákazníkovi tovar doručený v priebehu dvoch až troch dní. Práve tieto dva faktory pravdepodobne najviac ovplyvňujú zákazníkov pri výbere spôsobu dodania tovaru. Zákazníci pri využití služieb pošty sú s nimi väčšinou spokojní.

Výsledky prieskumu okrem iného ukázali aj to, že hotovost' sa v súčasnosti pomaly dostáva do úzadia a stáva sa vo vel'kej miere minulost'ou. Drvivá väčšina zákaznikov platí za tovar elektronicky. S tým sa takisto spája pohodlnost' a rýchlost' vybavenia platby, kedy predovšetkým odpadá nutnost' výberu peňazí.

Z prieskumu tiež vyplynulo, že zákazníci sú otvorení novým možnostiam a spôsobom dodania tovaru, akým je aj dodanie tovaru s pomocou dronu. V súčasnosti si to ešte väčšina nevie predstavit' a majú v tomto smere určité obavy, ako by takéto dodanie prebiehalo, či bude bezpečné a pod.

Další výskum bude smerovat’ do výraznejšej segmentácie zákazníkov v závislosti na tovare, ktorý je objednávaný a spôsobov riešenia poslednej míle. Zároveň je nutné sa zamerat' na možnosti spätnej logistiky a teda aj riešenia prvej míle z pohl'adu zákazníkov.

\section{Literatúra}

[1] ARIF, MSM., YAN, NS., ZAKUAN, N., BAHARI, AZ., JUSOH, A.: Web-based Factors Affecting Online Purchasing Behaviour. 2013 International Conference on Manufacturing, Optimization, Industrial and Material Engineering (MOIME 2013), 2013, ISSN 1757-8981

[2] CARDENAS, I., BECKERS, J., VANELSLANDER, T.: E-commerce last-mile in Belgium: Developing an external cost delivery index. Research in Transportation Business and Management, 2017, s. 123-129, ISSN 2210-5395

[3] JANJEVIC, M., WINKENBACH, M.: Characterizing urban last-mile distribution strategies in mature and emerging e-commerce markets. Transportation Research Part Apolicy nad Practice, 2020, s. 164-196, ISSN 0965-8564

[4] VAKULENKO, Y., SHAMS, P., HELLSTROM, D., HJORT, K.: Service innovation in e-commerce last mile delivery: Mapping the e-customer journey. Journal of Business Research, 2019, s. 461-468, ISSN 0148-2963

[5] LI, X., LIU, HF., ZHU, B.: Evolutive preference analysis with online consumer ratings. Information Science, 2020, s. 332-344, ISSN 0020-0255

[6] PILIK, M., JURICKOVA, E., KWARTENG, MA.: On-line shopping behaviour in the Czech Republic under the digital transformation of economy. Economic Annals-XXI, 2017, s. 119-123, ISSN 1728-6220

[7] LIUQU, YY., FAN, XH., FU, PL.: From Customer Satisfaction to Customer Experience: Online Customer Satisfacion Practice in International E-commerce. Cross-Cultural Design: Applications in Mobile Interaction, Education, Health, Transport and Cultural Heritage, CCD 2015, PT II, 2015, s. 80-89, ISSN 0302-9743

[8] DUMITRESCU, L., CETINA, I., PENTESCU, A., FUCIU, M.: Customer Satisfacion Premise in Gaining Customer Loyalty. 18th International Conference - The KnowledgeBased Organization: Management and Military Sciences, Conference Proceedings 1, 2012, s. 483-488, ISSN 1843-6722

[9] SIMANJUNTAK, M.: Consumer empowerment on online purchasing. Independence Journal of Management \& Production, 2020, s. 236-255, ISSN 2236-269X 
[10]3 spôsoby, ako doručit' balík či tovar ku zákazníkovi. 2019. [online]. Dostupné na: https://dociela.sk/logistika/3-sposoby-ako-dorucit-balik-ci-tovar-ku-zakaznikovi/

[11]REMOVČÍKOVÁ, L.: Hotovost', karta či mobil? Ktorá platobná metóda je najoblúbenejšou a ktorá najbezpečnejšia? 2019. [online]. Dostupné na: https://www.podnikajte.sk/informacne-technologie/hotovost-karta-ci-mobil-platobnametoda

[12] ABRAHAM, A.: How Technology is Improving Last-Mile Delivery in 2020. 2020. [online]. Dostupné na: https://yourstory.com/mystory/technology-improving-last-miledelivery-2020

\section{Grantová podpora}

Táto publikácia vznikla vd’aka podpore projektu VEGA 1/0011/21 Výskum interakcií medzi novými emergentnými technológiami, výkonnost’ou podnikov a odvetví založených na siet'ovej technologickej infraštruktúre, uplatňovaním nových business modelov a inštitucionálnym regulačným, environmentálnym a sociálnym prostredím . 